\title{
Revealing hidden diversity in the Sheathia arcuata morphospecies (Batrachospermales, Rhodophyta) including four new species
}

\author{
Morgan L.Vis ${ }^{1, *}$, Sunil Tiwari ${ }^{1}$, Joshua R. Evans ${ }^{1}$, Rosalina Stancheva ${ }^{2}$, Robert G. Sheath ${ }^{2, * *}$, \\ Bryan Kennedy ${ }^{3}$, Janina Lee ${ }^{4, * * *}$ and Pertti Eloranta ${ }^{5}$ \\ ${ }^{1}$ Department of Environmental and Plant Biology, Ohio University, Athens, OH 45701, USA \\ ${ }^{2}$ Department of Biological Sciences, California State University San Marcos, San Marcos, CA 92096, USA \\ ${ }^{3}$ Environmental Protection Agency, Castlebar, Co. Mayo, Ireland \\ ${ }^{4}$ Department of Freshwater Biology, Institute of Nature Conservation, PAS al. A. Mickiewicza 33, Kraków 31-120, Poland \\ ${ }^{5}$ Sinkilätie 13, Jyväskylä FI-40530, Finland
}

The freshwater red algal genus Sheathia contains species with heterocortication (both bulbous and cylindrical cells covering the main axis) and homocortication (only cylindrical cells). When the genus was proposed, the species with heterocortication were revised, but all specimens with homocortication were assigned to Sheathia arcuata with the caveat that it may represent a species complex. Recent studies have described new species with homocortication and $S$. arcuata has been rendered paraphyletic. In the current study, new sequences of the $r b c \mathrm{~L}$ and $5^{\prime}$ region of the cytochrome $c$ oxidase subunit I markers were combined with previously published data to construct a robust phylogeny and circumscribe new species. Four new species, S. abscondita, S. californica, S. plantuloides, and S. transpacifica are proposed. Examination of morphological characters among homocorticate species show no diagnostic characters to distinguish among species, whereas S. plantuloides is only known from sporophytes (chantransia) so it lacks the typical morphological characters derived from the gametophytes for comparison. Although DNA sequence data would be needed to make a positive species identification, geography could be employed to narrow the identification to one or two species. The genus is geographically widespread having been recorded from oceanic islands and five continents, whereas the individual species typically occur on a single continent. With this study, the number of species recognized in Sheathia is raised to 17; seven heterocorticate and 10 homocorticate, making this genus one of the most species rich in the Batrachospermales. As well, the resulting phylogeny provides insights into the evolution of heterocortication in Sheathia.

Key Words: COI-5P; freshwater; molecular phylogeny; rbcL; Sheathia; streams; systematics

Abbreviations: BI, Bayesian inference; BS, bootstrap support; COI-5P, $5^{\prime}$ region of the cytochrome $c$ oxidase subunit I; ML, maximum likelihood; PP, posterior probability; $r b c \mathrm{~L}$, ribulose-1,5-biphosphate

\section{INTRODUCTION}

The rhodophyte order Batrachospermales contains two-thirds of the known freshwater red algal species diversity. Systematics research has focused on delineating genera and species based on DNA sequence data and morphological evidence. The nominate genus Batrachospermum was once the most speciose in the order, but
(1) \$ This is an Open Access article distributed under the terms of the Creative Commons Attribution Non-Commercial License (http://creativecommons.org/licenses/by-nc/3.0/) which permits unrestricted non-commercial use, distribution, and reproduction in any medium, provided the original work is properly cited.
Received April 22, 2020, Accepted August 31, 2020

*Corresponding Author

E-mail: vis-chia@ohio.edu

Tel: +1-740-593-1134, Fax: +1-740-593-1130

${ }^{* *}$ Published posthumously

*** Previously published under the name Janina Kwandrans 
most sections have since been elevated to genus level and true Batrachospermum now contains only a handful of species (Vis et al. 2020). For example, members of the sections Acarposporophytum, Aristata, Macrospora, Turfosa, and Virescentia now belong to the genera Acarposporophycos, Visia, Montagnia, Paludicola, and Virescentia, respectively (Necchi et al. 2018, 2019a, 2019b, Vis et al. 2020).

Batrachospermum sections Batrachospermum and Helminthoidea were considered to be closely related based on morphology and at one time placed in synonymy (Vis et al. 1996, Kumano 2002). However, Salomaki et al. (2014) showed that members of these sections were distantly related based on DNA sequence evidence and thus proposed the genus Sheathia to accommodate section Helminthoidea. In the protologue, a distinctive morphological character of heterocortication, both bulbous and cylindrical cells comprising the cortication of the main axis, was documented and seven species with this character were delineated (Salomaki et al. 2014). However, the DNA sequence data also showed S. arcuata Kylin, with homocortication consisting of uniform cylindrical cells, to be within this genus clade and there remained a potential of hidden diversity within the species (Salomaki et al. 2014).

Sheathia arcuata was first described from Sweden and has since been reported from other locations in Europe, North America, Asia, Australasia, and the Pacific Islands based on morphology (Vis et al. 1996, 2010, Kumano 2002, Eloranta et al. 2011 and the references therein). This species has been distinguished from other morphologically similar species based on dioecy, carposporophytes at the periphery of whorls, and long involucral filaments of the carpogonial branch (Kylin 1912, Vis et al. 1996, Eloranta et al. 2011). A phylogeographic study of $S$. arcuata showed substantial genetic variation in the $r b c \mathrm{~L}$ gene and cox2-3 spacer among specimens that appeared to be geographically structured (Vis et al. 2010). Although there was genetic variability, a survey of morphology among specimens showed overlap in numerous characters used to distinguish species such that the researchers did not propose new species (Vis et al. 2010). Salomaki et al. (2014) added more specimens to one of the S. arcuata sub-clades and observed heterocortication on the lower part of smaller specimens; subsequent analysis resulted in the description of S. exigua Salomaki \& M. L. Vis.

Recent systematic research within the genus Sheathia has revealed more diversity of species. From China, four species, S. longipedicellata (D. Hua \& Z. X. Shi) J. F. Han, F. R. Nan, J. Feng, J. P. Lv, Q. Liu, Kociolek \& S. L. Xie, S. hongdongensis (S. L. Xie \& J. Feng) J. F. Han, F. R. Nan, J. Feng, J. P. Lv, Q. Liu, Kociolek \& S. L. Xie, S. jinchengensis J. F. Han, F. R. Nan, J. Feng, J. P. Lv, Q. Liu, Kociolek \& S. L. Xie and S. matouensis J. F. Han, F. R. Nan, J. Feng, J. P. Lv, Q. Liu, X. D. Lui \& S. L. Xie have been added to Sheathia based on DNA sequence data (Li et al. 2010, Ji et al. 2014, Han et al. 2018, 2019). In a study of specimens from Nepal and India, three new species were proposed S. assamica Necchi, J. A. West, E. K. Ganesan \& F. Yasmin, S. dispersa Necchi, J. A. West, E. K. Ganesan \& S. K. Rai and S. indonepalensis Necchi, J. A. West, E. K. Ganesan, S. K. Rai \& F. Yasmin (Necchi et al. 2019c). Sheathia dispersa includes specimens from Hawaii, Indonesia and Taiwan that were previously attributed to $S$. arcuata (Vis et al. 2010, Johnston et al. 2014, Necchi et al. 2019c). Lastly, $S$. murphyi A. L. Szinte, J. C. Taylor \& M. L. Vis from Africa is the most recently described species (Szinte et al. 2020). Importantly, these new species have rendered S. arcuata paraphyletic in $r b c$ L phylogenies (Necchi et al. 2019c, Szinte et al. 2020). Since the proposal of the genus, cryptic diversity has been suggested in S. arcuata based on DNA sequence data (Salomaki et al. 2014).

A wealth of new $r b c \mathrm{~L}$ sequence data from the recently described homocorticate species in Sheathia is now available. In addition, the paraphyly of $S$. arcuata needs to be addressed. Therefore, the present study was undertaken to provide a comprehensive assessment of Sheathia focused on the homocorticate species as well as examining the relationship of homocorticate and heterocorticate species. To accomplish these goals, sequences were generated and combined with data from GenBank to produce a robust phylogeny. Both DNA sequence data and morphological observations were used to circumscribe monophyletic species.

\section{MATERIALS AND METHODS}

\section{Sample collection}

New specimens were collected from the USA (California), Finland, Ireland, and Poland (Supplementary Table S1). A portion of the sample was dried in silica desiccant and another either preserved in $2.5 \%$ glutaraldehyde or pressed on herbarium paper as a morphological voucher. The specimens from California were gametophytes and those from Finland, Ireland, and Poland were the chantransia stage (filamentous sporophyte). The morphological vouchers are housed at the Floyd Bartley Herbarium at Ohio University (BHO), Institute of Nature Conservation, 
Polish Academy of Sciences (ZTS), National Herbarium of New South Wales (NSW), and University Herbarium at the University of California, Berkeley (UC) (Thiers 2020).

\section{DNA extraction and amplification}

Silica desiccated specimens were ground in liquid nitrogen and extracted using the NucleoSpin Plant II DNA kit (Macherey-Nagel, Düren, Germany) following the manufacturer's protocol. A 1,282-base pair (bp) region of the plastid-encoded ribulose-1,5-bisphosphate $(r b c \mathrm{~L})$ gene was PCR amplified using primers F160 and rbcLR (Vis et al. 1998). A 664-bp portion of the mitochondrial encoded cytochrome oxygenase 1 gene (COI-5P) was amplified using GazF1 and GazR1 primers (Saunders 2005). PCR products were generated using either Ex Taq DNA Polymerase (TaKaRa Bio Company, Tokyo, Japan) with the $50 \mu \mathrm{L}$ PCR cocktail consisting of $36.75 \mu \mathrm{L} \mathrm{dH}_{2} \mathrm{O}$, $1.5 \mu \mathrm{L}$ forward primer, $1.5 \mu \mathrm{L}$ reverse primer, $5 \mu \mathrm{L}$ Ex Taq Buffer, $4 \mu \mathrm{L}$ Ex Taq dNTPs, $0.25 \mu \mathrm{L}$ Ex Taq polymerase, and $1 \mu \mathrm{L}$ DNA template, or Illustra PuReTaq Ready to Go PCR Beads (GE Healthcare, Piscataway, NJ, USA), with 19 $\mu \mathrm{L} \mathrm{dH_{2 }} \mathrm{O}, 2 \mu \mathrm{L}$ of each primer, and $2 \mu \mathrm{L}$ DNA template. PCR parameters for $r b c \mathrm{~L}$ gene amplification were initial denaturation for $1 \mathrm{~min}$ at $95^{\circ} \mathrm{C}, 35$ cycles of $30 \mathrm{~s}$ at $93^{\circ} \mathrm{C}$, $30 \mathrm{~s}$ at $50^{\circ} \mathrm{C}, 1 \mathrm{~min}$ at $68^{\circ} \mathrm{C}$ and final extension $10 \mathrm{~min}$ at $72^{\circ} \mathrm{C}$ and for COI-5P, initial denaturation $1 \mathrm{~min}$ at $94^{\circ} \mathrm{C}$, 40 cycles of $1 \mathrm{~min}$ at $94^{\circ} \mathrm{C}, 1: 30 \mathrm{~min}$ at $50^{\circ} \mathrm{C}, 1 \mathrm{~min}$ at $72^{\circ} \mathrm{C}$ and final extension $10 \mathrm{~min}$ at $72^{\circ} \mathrm{C}$. The PCR products were purified using either UltraClean PCR Clean-up DNA Purification Kit (Mo Bio, Carlsbad, CA, USA) or Invitrogen PureLink Quick PCR Purification Kit (Life Technologies, Carlsbad, CA, USA) following the manufacturers' protocols. The purified PCR products were sequenced at the Ohio University Genomics Facility using the amplification primers for both markers and two internal primers F650 and R897.1 (Salomaki et al. 2014) for the longer $r b c \mathrm{~L}$ so that sequence data were obtained for the full length of the sense and anti-sense strands.

For two previously collected specimens with published $r b c \mathrm{~L}$ data (one from Italy and one from Washington State, USA) (Supplementary Table S1), the COI-5P was PCR amplified and sequenced as described previously. Raw sequence reads for each sample were assembled using Sequencher 5.2.4 (Gene Codes Corp., Ann Arbor, MI, USA). Sequence data were deposited in GenBank (Supplementary Table S1).

\section{Sequence analyses}

All sequence data of the $r b c \mathrm{~L}$ and COI-5P generated in this study and those sequences attributable to the Sheathia arcuata complex in GenBank were evaluated for inclusion in the final data set for phylogenetic analyses (Supplementary Table S1). Specimens with $r b c$ L sequence $<1,100 \mathrm{bp}$ or identical in sequence to another specimen were not used in the phylogenetic analyses. Therefore, the data set included specimens with both $r b c \mathrm{~L}$ and COI$5 \mathrm{P}$ data that were not identical to other specimens and specimens with only $r b c \mathrm{~L}$ data but were either unique or represented the only sequence for a species. Sequences were trimmed, when needed, to 1,282 bp for the $r b c \mathrm{~L}$ and $664 \mathrm{bp}$ for the COI-5P. Sequences were also scrutinized for quality and in some cases, base pairs near one or both ends were removed, if the evaluation showed that they were non-coding for protein sequence. The dataset had 42 sequences, 17 specimens with both $r b c \mathrm{~L}$ and COI-5P and 25 specimens with $r b c \mathrm{~L}$ only. Fourteen representative specimens of the seven heterocorticate Sheathia species (Supplementary Table S1) as well as 33 specimens from all other genera in the Batrachospermales and Thoreales (Supplementary Table S2) completed the data set of 89 specimens (64 concatenated $r b c \mathrm{~L} / \mathrm{COI}-5 \mathrm{P}$ and 25 $r b c \mathrm{~L}$ only).

Maximum likelihood (ML) using RAxML 8 (Stamatakis 2014) and Bayesian inference (BI) analysis using MrBayes v.3.2.6 (Huelsenbeck and Ronquist 2001) were run as plug-ins in Geneious Prime 2020.0.5 (https://www.geneious.com). For both the ML and BI analyses, a GTR + $\mathrm{G}$ model was employed. Support values were determined using 1,000 ML bootstrap (bs) replicates and BI posterior probabilities (pp) determined from $3 \times 10^{6}$ generations with sampling every 100 generations and the first 250 generated trees removed as burn-in. Species delimitation was explored for both $r b c \mathrm{~L}$ and COI-5P data sets using the Automatic Barcode Gap Discovery (ABGD) accessed through the graphical website (https://bioinfo.mnhn.fr/ abi/public/abgd/) with all default parameters and using simple distance (SD) and Jukes-Cantor (JC) (Puillandre et al. 2012).

\section{Morphological analyses}

The morphology of newly collected specimens as well as the New Zealand (TJE3094), and Washington (KC01 and KC13) specimens was examined to compare with data from other species within Sheathia with homocortication. The specimens from California, New Zealand, 


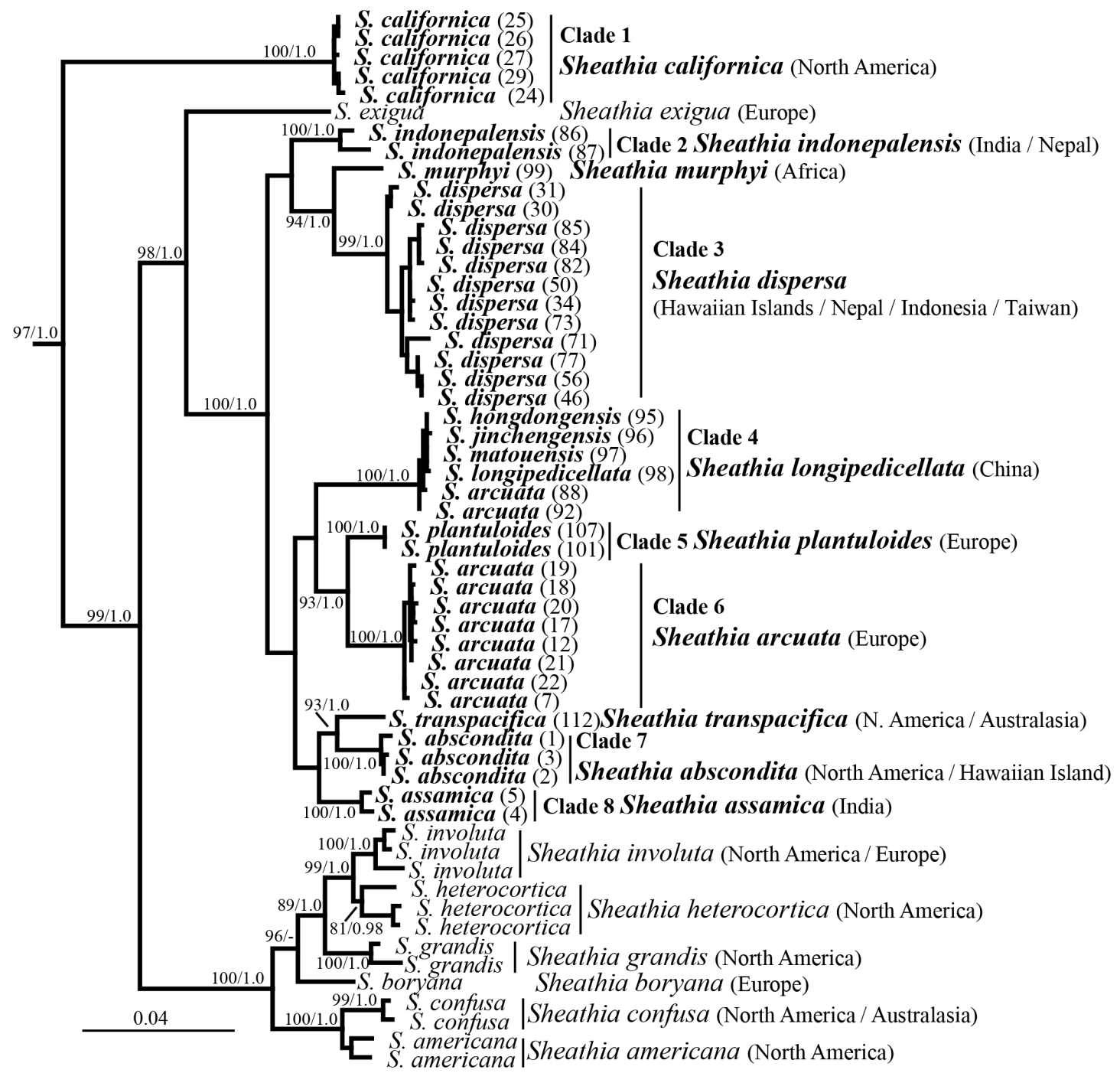

Fig. 1. Maximum likelihood phylogeny depicting the relationship of among Sheathia species and the genus Sheathia with other genera of Batrachospermales based on $r b c \mathrm{~L}$ and $5^{\prime}$ region of the cytochrome $c$ oxidase subunit I (COI-5P) concatenated and $r b c \mathrm{~L}$ alone sequence data. Support values are shown as bootstrap (bs) / posterior probability (pp) from Bayesian inference. A dash (-) indicate support $<80 \%$ bs / 0.8 pp. Bold face indicates specimens / species within Sheathia with homocortication. Numbers in parentheses are specimens in Supplementary Table S1. GenBank numbers for Sheathia specimens in Supplementary Table S1. Outgroup taxa of Thoreales and Batrachospermales are not shown in the final tree but provided in Supplementary Table S2.

and Washington were gametophytes such that morphological characters typically used to distinguish species in Sheathia were assessed including measurements of gametophyte whorls and fascicle cell number, carpogonia, carpogonial branch, carposporophytes, and carposporangia (Salomaki et al. 2014, Necchi et al. 2019c). The specimens from Finland, Ireland, and Poland were of the chantransia stage. Therefore, only measurements of the vegetative cells and monosporangia were possible.

\section{RESULTS}

\section{Molecular analyses}

Sequence data for $r b c \mathrm{~L}$ was generated for 19 specimens and COI-5P for six specimens (Supplementary Table S1). Some of the new sequences were identical to one other or to previously published sequences. Unique $r b c \mathrm{~L}$ sequences and sequences that had both gene regions from the same individual were used in the phylogenetic analyses. 
Phylogenetic analyses using both ML and BI showed similar topology and only the ML analysis is shown (Fig. 1). Support values for the genus Sheathia were high (97 bs and $1.0 \mathrm{pp}$ ). There was high support ( $>93$ bs and 1.0 pp) for eight clades and two individual sequences with homocortication (Fig. 1, all sequences in bold). Clade 1 including specimens $24-27$ and 29 with homocortication was early divergent lineage with high support. The recently described species S. assamica (Clade 8), S. dispersa (Clade 3), S. indonepalensis (Clade 2), and S. murphyi were all well-supported. S. arcuata specimens from Europe formed Clade 6 ( $100 \mathrm{bs}$ and $1.0 \mathrm{pp}$ ). Clade 4 consisted of specimens from China attributed to $S$. arcuata, $S$. hongdongensis, S. jinchengensis, S. longipedicellata, and S. matouensis was fully supported. Two specimens (101, 107) of Clade 2 were genetically distinct and sister to $S$. arcuata. Likewise, three specimens (1-3) formed Clade 7 sister to specimen 112 , which was genetically more distant (Fig. 1).

Species delineation using ABGD using each gene separately placed specimens with homocortication in groups that were similar to the clades and independent sequences defined in the phylogenetic analysis (Fig. 1, Supplementary Figs S1 \& S2). For the $r b c \mathrm{~L}$ marker, there was a total of 114 sequences that were partitioned into nine groups using the SD, and 14 groups using the JC model (Supplementary Fig. S1). The nine SD groups corresponded to the eight clades plus two independent sequences in the phylogenetic analyses, but S. murphyi was placed in a group with $S$. dispersa. In contrast, the 14 JC groups differed in S. murphyi being a separate group and S. dispersa being divided into five groups (Supplementary Fig. S1). For the COI-5P, there were no sequences for $S$. assamica or S. indonepalensis, but there were sequences representing the other six clades and two individual sequences from the phylogenetic analyses. There was a total of 45 sequences that were partitioned into 10 groups using SD and 11 groups using JC (Supplementary Fig. S2). Seven groups were consistent with the phylogenetic analysis, but $S$. dispersa was divided into three or four groups, respectively. Sequence divergence among the 56 S. dispersa $r b c \mathrm{~L}$ sequences was $<1.1 \%$ and among $35 \mathrm{~S}$. dispersa COI-5P sequences was $\leq 2 \%$. S. murphyi differed from $S$. dispers $a$ by $>2 \%$ in $r b c \mathrm{~L}$ and $>5 \%$ in COI-5P. Given the low interspecific genetic diversity within $S$. dispersa and the twice as great interspecific difference between S. dispersa and S. murphyi, we consider the S. dispersa sequences to represent a single species with $S$. murphyi being distinct.

\section{Morphological analyses}

Newly collected and sequenced specimens were examined for morphological characters used in species identification (Fig. 2). Gametophyte specimens (California, Washington, and New Zealand) had morphological characteristics of the genus. The whorls were well-developed, confluent, barrel-shaped or spherical for both female and male thalli (Fig. 2A, E, G, L \& O). When present, carposporophytes were pedicellate, spherical and at various distances from the main axis (Fig. 2A \& G). The carpogonial branches were composed of numerous cells undifferentiated from fascicle cells (Fig. 2B, C, H, M \& N). The carpogonia had clavate trichogynes that ranged in length (Fig. 2B, C, H, M \& N). It was not uncommon to observe secondary carpogonia at the tips of involucral filaments (Fig. 2B, H \& M). Gonimoblasts were densely arranged with obovoidal carposporangia at branch tips (Fig. 2D \& I). Spermatangia were spherical at the tips of primary fascicles (Fig. 2F, J \& P). Measurements of morphological characteristics from this study and other studies is provided in Table 1. The samples from Ireland, Finland and Poland were chantransia, which have long cylindrical vegetative cells and obovoidal monosporangia, when present, at the tips of branches (Fig. 2K).

\section{Taxonomic proposals}

Sheathia abscondita sp. nov. Stancheva, Sheath et M. L.Vis (Fig. 2A-F)

Description. Plants dioecious; olive-drab to dark bluegreen, sometimes slightly purple; branching irregular; whorls well-developed, confluent, barrel-shaped or spherical, 178-920 $\mu \mathrm{m}$ diameter; main axis covered in regular, cylindrical cortication (homocortication); primary fascicles with cells ranging from cylindrical to ellipsoidal to obovoidal, 17-23 cells; secondary fascicles sparse; spermatangia spherical or subspherical, terminal on primary fascicles, 5-6 $\mu \mathrm{m}$ in diameter; carpogonial branches composed of cells similar to the fascicles, straight, developing from the periaxial, proximal cells of primary fascicles and occasionally from distal cells of primary fascicles, 2-8 cells; involucral filaments, short near the carpogonium and longer at the base of the branch, composed of cylindrical or ellipsoidal cells; carpogonia 25-44 $\mu \mathrm{m}$ in length, 6.7-9.1 $\mu \mathrm{m}$ diameter, with clavate to lanceolate trichogynes; carposporophytes 1-5 (-6) per whorl, 62-151 $\mu \mathrm{m}$ in diameter; gonimoblast filaments densely arranged, composed of 2-4 (-5) barrel-shaped to cylindrical cells; carposporangia obovoidal, 10.2-14.0 $\mu \mathrm{m}$ 

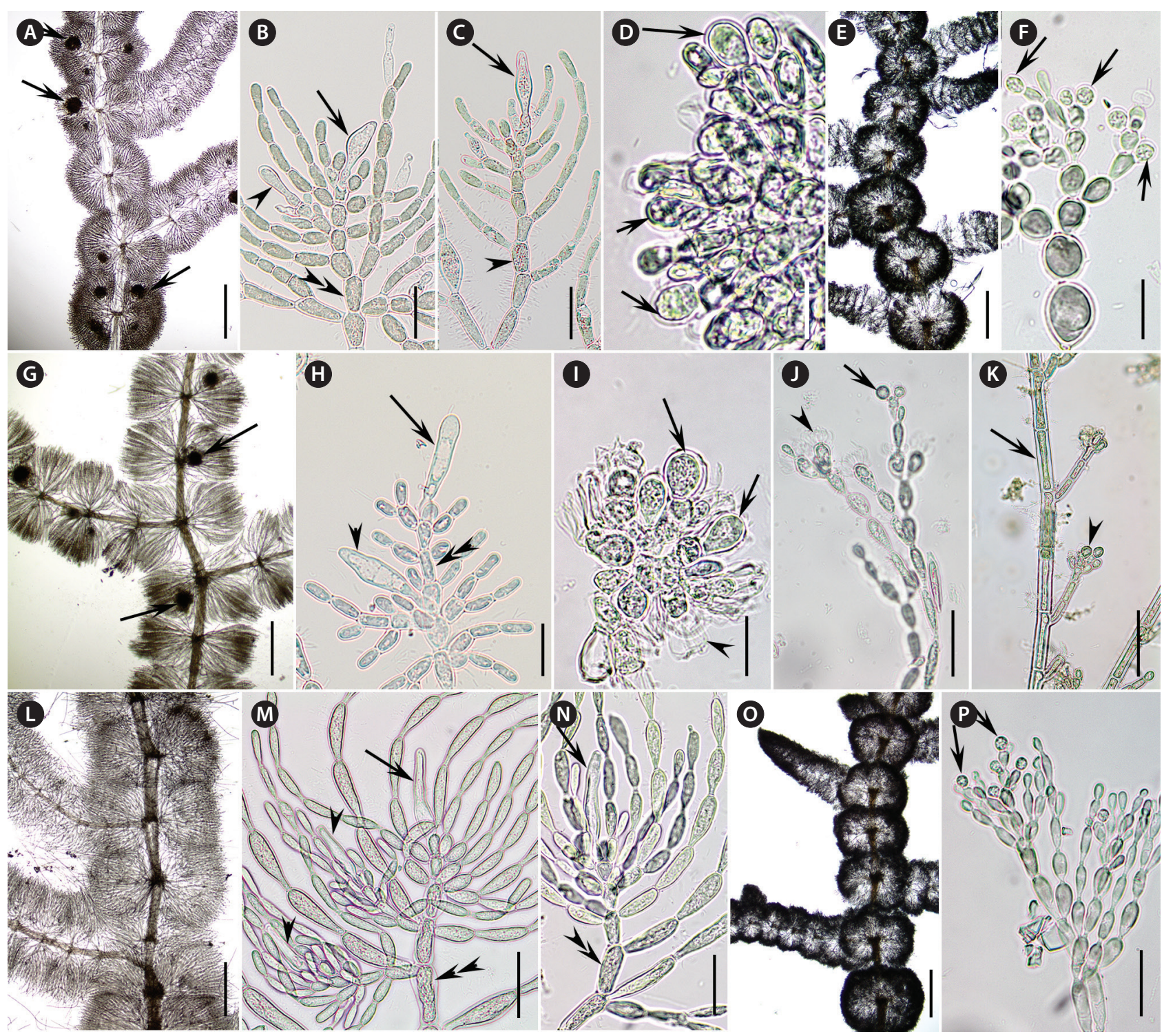

Fig. 2. Morphological characteristics of proposed Sheathia species. Photomicrographs from the holotype or isotype specimens unless otherwise noted. (A-F) Morphological characteristics of S. abscondita sp. nov. (A) Female thallus having confluent barrel-shaped, spherical whorls with few secondary fascicles and small pedicellate spherical carposporophytes (arrows). (B) Carpogonium with clavate trichogyne (arrow) at the tip of a carpogonial branch (double arrowhead) composed of cells undifferentiated from fascicles and a developing carpogonium (arrowhead) at the tip of an involucral filament. (C) Carpogonium with lanceolate trichogyne (arrow) at the tip of a long carpogonial branch (arrowhead) composed of cells undifferentiated from fascicles. (D) Dense carposporophyte with obovoidal carposporangia (arrows) at gonimoblast tips. (E) Male thallus having confluent spherical whorls with few secondary fascicles (BHO A-1665). (F) Spermatangia (arrows) at fascicle tips (BHO A-1665). (G-J) Morphological characteristics of S. californica sp. nov. (G) Female thallus having separated barrel-shaped, whorls with few secondary fascicles and small pedicellate spherical carposporophytes (arrows) (BHO A-1654). (H) Carpogonium with ellipsoidal trichogyne (arrow) at the tip of a carpogonial branch (double arrowhead) composed of cells undifferentiated from fascicles and a carpogonium with clavate trichogyne (arrowhead) on the carpogonial branch. (I) Dense carposporophyte with obovoidal carposporangia (arrows) and remnants (arrowhead) at gonimoblast tips (BHO A-1655). (J) Spermatangium (arrowhead) and remnants of spermatangia (arrow) at fascicle tips (BHO A-1656). (K) Morphology of S. plantuloides sp. nov. with cylindrical vegetative cells (arrow) and obovoidal monosporangia (arrowhead). (L-P) Morphological characteristics of S. transpacifica sp. nov. (L) Female thallus having confluent barrel-shaped, whorls with few secondary fascicles. (M) Carpogonium with elongate-lanceolate trichogyne (arrowheads) at the tip of a carpogonial branch (double arrowhead) composed of cells undifferentiated from fascicles and carpogonia (arrow) at the tip of involucral filaments. (N) Carpogonium with elongate-ellipsoidal trichogyne (arrow) at the tip of a long carpogonial branch (double arrowhead) composed of cells undifferentiated from fascicles. (O) Male thallus having confluent spherical whorls with few secondary fascicles (BHO A-1663). (P) Spermatangia (arrows) at fascicle tips (BHO A-1663). Scale bars represent: A, E, G, L \& O, $400 \mu \mathrm{m} ; \mathrm{B}, \mathrm{C}, \mathrm{H}, \mathrm{J}, \mathrm{K}, \mathrm{M} \& \mathrm{P}, 50 \mu \mathrm{m} ; \mathrm{D}$, $\mathrm{F}, \mathrm{I} \& \mathrm{~N}, 30 \mu \mathrm{m}$. 


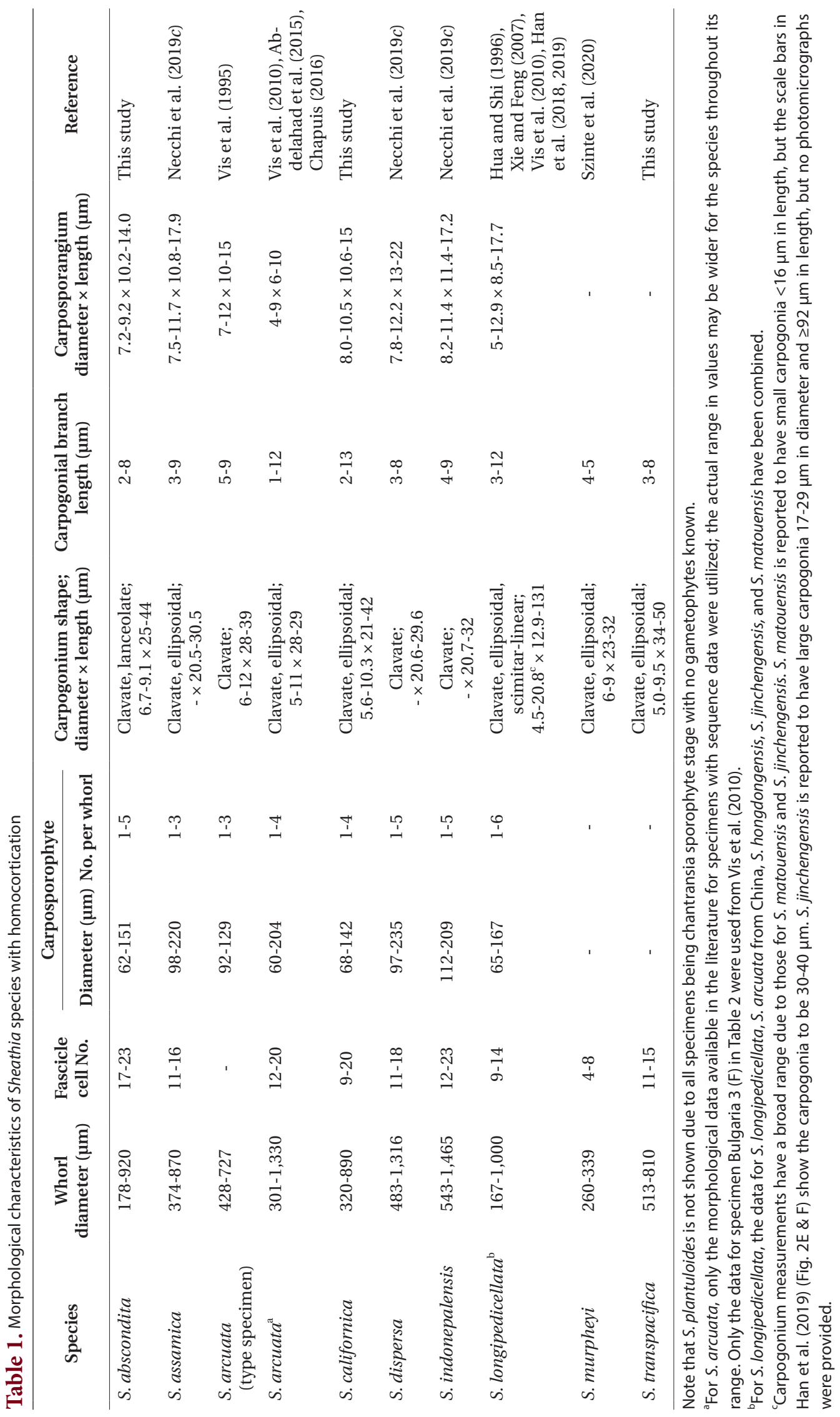


in length, 7.2-9.2 $\mu \mathrm{m}$ diameter.

Holotype. UC2085028, USA, California, South Fork Garcia River above Garcia River, SWAMP site 113GAR110, 38.8553 N, 123.56022 W, Coll. R. Fadness, Jul 15, 2015, Isotype, BHO A-1653.

Representative DNA sequences. GenBank MT441833 (rbcL), MT441852 (COI-5P).

Etymology. This species epithet means hidden as its occurrence from California, Washington and Hawaii was hiding among other Sheathia species that are more common in those locations.

Paratype. BHO A-1665, USA, Washington, Kimball Creek, Snoqualmie, on Meadowbrook way, 47.526816 N, 121.812317 W, Coll. M. Vis and M. Hall, Mar 19, 1999.

Distribution. This species has been collected from three locations, one each in California, Hawaii, and Washington, USA.

Remarks. The geographic ranges of this species and those of both S. californica and S. transpacifica overlap and the species cannot be distinguished based on morphology alone. In addition, a chantransia specimen was collected in the Hawaiian Islands where S. dispersa is widely distributed. DNA sequence data are needed for a positive identification.

Environmental data. Water temperature $15.9^{\circ} \mathrm{C}$, conductivity $184 \mu \mathrm{S} \mathrm{cm}^{-1}$, pH 7.52, chloride $9.4 \mathrm{mg} \mathrm{L}^{-1}$, TN 0.1 $\mathrm{mg} \mathrm{L}^{-1}$, TP $0.035 \mathrm{mg} \mathrm{L}^{-1}$, DOC $0.86 \mathrm{mg} \mathrm{L}^{-1}$, sulfate $8.3 \mathrm{mg}$ $\mathrm{L}^{-1}$.

Sheathia californica sp. nov. Stancheva, Sheath et M. L. Vis (Fig. 2G-J)

Description. Plants monecious or dioecious; purple to reddish with yellow-brownish hue, sometimes dark bluish; branching irregular; whorls well-developed, confluent, barrel-shaped or spherical, 320-890 $\mu \mathrm{m}$ diameter; main axis covered in regular, cylindrical cortication (homocortication); primary fascicles with cells ranging from cylindrical to ellipsoidal and obovoidal, (9-) 12-18 (-20) cells; secondary fascicles few and sparse; spermatangia spherical or subspherical, terminal on primary fascicles, 4.8-5.3 $\mu \mathrm{m}$ in diameter; carpogonial branch composed of cells similar to the fascicles, straight, developing from the periaxial, proximal cells of primary fascicles and occasionally from distal cells of primary fascicles, 2-13 cells; involucral filaments, short or long, composed of cylindrical or ellipsoidal cells; carpogonia with clavate to ellipsoidal trichogynes, 21-42 $\mu \mathrm{m}$ in length, 5.6-10.3 $\mu \mathrm{m}$ diameter; carposporophytes 1-4 per whorl, 68-142 $\mu \mathrm{m}$ in diameter; gonimoblast filaments densely arranged, composed of 2-4 barrel-shaped to cylindrical cells; carpospo- rangia obovoid, 10.6-15.0 (-16.3) $\mu \mathrm{m}$ in length, (7.5-) 8.010.5 (-13.1) $\mu \mathrm{m}$ diameter.

Holotype. UC2085029, USA, Signal Creek at Big Cheese Road, Garcia River Watershed, SWAMP site 113GAR178, 38.8748 N, 123.4937 W, Coll. R. Fadness, Aug 16, 2016.

Representative DNA sequences. GenBank MT441834 ( $r b c \mathrm{~L}$ ), MT441854 (COI-5P).

Etymology. This species epithet signifies that this species occurs in California, USA.

Paratypes. BHO A-1654, USA, California, Clarks Creek above Hwy 199, 41.80827 N, 124.11215 W, no collector information, Jul 15, 2015; BHO A-1655, USA, California, Clarks Creek above Hwy 199, 41.80827 N, 124.11215 W, no collector information, Jun 13, 2016; BHO A-1656, USA, California, Bear Creek 1.4 miles above Canyon Creek, $40.90353 \mathrm{~N}, 123.01368 \mathrm{~W}$, no collector information, Jul 20, 2015.

Distribution. This species has been collected from streams in California, USA.

Remarks. This species and S. abscondita both occur in California and cannot be distinguished based on morphology alone. The type localities of both species are within Garcia watershed, but S. californica is more widely distributed across the state, also recorded in Eel River, Canyon Creek, Soda Creek and Clarks Creek watersheds. DNA sequence data are needed for a positive identification.

Environmental data. Water temperature $11.7-15.9^{\circ} \mathrm{C}$, conductivity 59-162 $\mu \mathrm{S} \mathrm{cm}^{-1}$, pH 7.1-7.8, chloride 0.3-7.6 $\mathrm{mg} \mathrm{L}^{-1}$, TN 0.06-0.09 $\mathrm{mg} \mathrm{L}^{-1}$, TP 0.007-0.057 $\mathrm{mg} \mathrm{L}^{-1}$, DOC 0.51-0.99 $\mathrm{mg} \mathrm{L}^{-1}$, sulfate $2.7-7.8 \mathrm{mg} \mathrm{L}^{-1}$.

\section{Sheathia plantuloides sp. nov. M. L. Vis (Fig. 2K)}

Description. Only the chantransia sporophyte stage has been collected to date. Thalli bluish-green to red in color, forming small tufts on surfaces. Thalli consisting of branched filaments with vegetative cells 7.8-14.5 $\mu \mathrm{m}$ in diameter and (21.6-) 28.3-50.0 (-61.0) $\mu \mathrm{m}$ in length. Monosporangia obovoidal, in clusters or singly at branch tips; (4.8-) 6.0-9.3 $\mu \mathrm{m}$ in diameter and (6.7-) 8.0-11.1 $(-12.8) \mu \mathrm{m}$ in length.

Holotype. BHO A-1658, Poland, River Bóbr, 51.256233 N, 15.520893 E, J. Lee, P. Eloranta \&W. Kowalski, May 16, 2011, Isotype ZTS.

Representative DNA sequence. GenBank MT441849 (rbcL), MT441856 (COI-5P).

Etymology. The species epithet means seedling-like and denotes that this species has only been collected as a small chantransia and has not yet developed into a large gametophyte. 
Paratypes. BHO A-1657, Poland, Jedlica S., Kowary, 50.802549 N, 15.824564 E, Coll. J. Lee, P. Eloranta \& W. Kowalski, May 23, 2011; BHO A-1659, Poland, Prądnik River, 50.242541 N, 19.783659 E, Coll. J. Lee \& P. Eloranta, Apr 12, 2012; BHO A-1660, Finland, Haapamäenkoski, Jämsä, 61.742290 N, 24.752009 E, Coll. J. Lee \& P. Eloranta, Aug 19, 2011.

Distribution. This species has been collected from numerous locations in Europe (Finland, Ireland, and Poland).

Remarks. To date, this species is only known from the chantransia sporophyte stage and no gametophyte specimens have been collected. Since all morphological characters to compare species of Sheathia are derived from the gametophyte, this species can only be distinguished based on DNA sequence data. The distribution overlaps that of its sister species, Sheathia arcuata. Widespread in Ireland in oligo-mesotrophic peatland rivers with mixed intensive landcover or aquaculture. Batrachospermales gametophytes are typically absent in summer and autumn surveys over the past several decades in the reported waterbodies, but this taxon has been recorded co-occurring with Lemanea fluviatilis, Torularia atra and diverse phytobenthos assemblages.

Environmental data. Poland (Bóbr R.): water temperature $14.0^{\circ} \mathrm{C}$, conductivity $216 \mu \mathrm{S} \mathrm{cm}^{-1}, \mathrm{pH}$ 7.9; Ireland: water temperature $3.9-20.2^{\circ} \mathrm{C}$, conductivity $34-261 \mu \mathrm{S} \mathrm{cm}^{-1}$, pH 5.6-7.8, chloride 5.5-33.1 mg L-1, TON 0.1-1.2 $\mathrm{mg} \mathrm{L}^{-1}$, $\mathrm{NH}_{4}-\mathrm{N}$ 0.01-0.04 mg L-1, ortho-P 5-25 $\mu \mathrm{g} \mathrm{L}^{-1}$, True Color 6-211 $\mathrm{mg} \mathrm{L}^{-1} \mathrm{Pt}$ Co.

\section{Sheathia transpacifica sp. nov. M. L.Vis (Fig. 2L-P)}

Description. Plants dioecious; olive-drab, purple to reddish; branching irregular; whorls well-developed, confluent, barrel-shaped or spherical, 513-810 $\mu \mathrm{m}$ diameter; main axis covered in regular, cylindrical cortication (homocortication); primary fascicles with cells ranging from cylindrical to ellipsoidal and obovoidal or pearshaped, 11-15 cells; secondary fascicles few and sparse; spermatangia spherical or obovoid, terminal on primary fascicles, 4.6-5.9 $\mu \mathrm{m}$ in diameter; carpogonial branch composed of cells similar to the fascicles, straight, developing from the periaxial, proximal cells of primary fascicles and occasionally from distal cells of primary fascicles or involucral filaments, 3-8 cells; involucral filaments, primarily long, composed of cylindrical or ellipsoidal cells that envelope the carpogonium; carpogonia with clavate, long-clavate and ellipsoidal/fusiform trichogynes, (28-) 34-50 (-68) $\mu \mathrm{m}$ in length, 5.0-9.5 $\mu \mathrm{m}$ diameter; carposporophytes not observed.
Holotype. NSW1060885, New Zealand, Wairarapa Stream (into Avon R), Jellie Park, Burnside, c. $5 \mathrm{~km} \mathrm{NW}$ of Christchurch, 43.508585 S, 172.584051 E, T. J. Entwisle, Nov 24, 2000, Isotypes, NSW1060887, BHO A-1664.

Paratype. BHO A-1663, USA, Washington, Snoqualmie, Kimball Creek on Meadowbrook Way, 47.526816 N, 121.812317 W, Coll. M. L. Vis \& M. M. Hall, Mar 19, 1999.

Representative DNA sequences. GenBank DQ393130 ( $r b c \mathrm{~L}), \mathrm{MT} 441857$ (COI-5P).

Etymology. This species epithet signifies that this species has crossed the Pacific Ocean as it is known from Washington, USA and New Zealand.

Distribution. This species has been collected from two locations in Washington state, USA and New Zealand.

Remarks. This species and S. abscondita both occur in Washington state and cannot be distinguished based on morphology alone. DNA sequence data are needed for a positive identification.

\section{Nomenclatural changes}

Sheathia longipedicellata (D. Hua \& Z.X. Shi) J. F. Han, F. R. Nan, J. Feng, J. P. Lv, Q. Liu, Kociolek \& S. L. Xie

Heterotypic synonyms. Sheathia hongdongensis (S. L. Xie \& J. Feng) J. -F. Han \& al. 2018, p. 68, Sheathia jinchengensis J. -F. Han \& al. 2018, p. 65, Fig. 1, S. matouensis J. -F. Han \& al. 2019, p. 257, Fig. 2a-f.

Remarks. $r b c \mathrm{~L}$ sequence similarity of specimens attributable to these species as well as S. arcuata from China is high. Although these species were distinguished based on morphology, those characters may be the result of environmental factors or measurement errors and are not considered taxonomically informative in this study.

\section{DISCUSSION}

With the description of new homocorticate species, the paraphyly of Sheathia arcuata has been resolved. S. arcuata was originally described from Sweden (Kylin 1912) and in the current taxonomic scheme, it is restricted to Europe with locations from Bulgaria, France, Italy, Spain, and UK confirmed via DNA sequences. It is probably more widespread in Europe given the records based on morphology provided in Eloranta et al. (2011), but some reports may be S. plantuloides, which would need to be confirmed via DNA sequence data. Given the data provided in this study, any records of S. arcuata from locations outside of Europe should be scrutinized and potentially be referred to one of the other homocorticate 
species based on geographic distribution.

Although S. arcuata and four endemic Sheathia species have been reported from China, we recognize a single species $S$. longipedicellata, using the oldest species epithet for species from that region. Previous studies have noted unique morphological characteristics primarily for the shape and size of the carpogonium and smaller whorl diameter (Hua and Shi 1996, Han et al. 2018, 2019). A scimitar-shaped or curved carpogonium was noted for S. hongdongensis in the protologue and the drawings for S. longipedicellata show similar shaped carpogonia (Hua and Shi 1996). S. matouensis was distinguished for having very small carpogonia (12.5-15.3 $\mu \mathrm{m})$, but the scale bars for the photomicrographs in the protologue indicate the carpogonia to be $30-40 \mu \mathrm{m}$, well within the range of other species in the genus (Han et al. 2019) (Table 1). Likewise, the whorl diameter range of $181.8-477.3 \mu \mathrm{m}$ is within the range of other Sheathia species (Table 1). S. jinchengensis was noted to have large carpogonia $(17-29 \mu \mathrm{m}$ in diameter and $>92 \mu \mathrm{m}$ in length) (Han et al. 2018). Carpogonia of this size would be notable and diagnostic, but unfortunately there were no photomicrographs or drawings of these structures. Both S. matouensis and S. jinchengensis were described as having heterocortication but the photomicrographs only show slightly inflated cells such that we would characterize them as having homocortication. Therefore, most of the morphological data are not compelling to designate separate species and the $r b c \mathrm{~L}$ and COI-5P sequence data place these species in a single clade with little genetic variation.

Among the homocorticate species, identification of species based on morphological characters would be difficult given the overlap in characters typically used to distinguish species. Even the most recent reports on the genus have noted the lack of defining morphological characters when describing new species (Necchi et al. 2019c, Szinte et al. 2020). Although DNA sequence data are needed to make a positive species identification, geographic pattern of distribution could be employed to narrow the identification to one or two species. A specimen from Europe would likely be either $S$. arcuata or $S$. plantuloides; one from California would likely be S. californica, which is the most common species locally, or S. abscondita which is so far known only from the type locality only. The need for DNA sequence or geographic data to distinguish among morphologically similar species has been noted in other genera of the order such as Batrachospermum, Virescentia, and Volatus (Chapuis et al. 2017, Necchi et al. 2018).

For two species (S. dispersa and S. plantuloides), the majority of specimens used for sequence analyses are chantransia stage sporophytes. S. dispersa has been reported as gametophytes from Nepal and Taiwan, but as sporophytes (chantransia) from Indonesia and numerous collections from the Hawaiian Islands (Chou and Wang 2006, Chiasson et al. 2007, Carlile and Sherwood 2013, Johnston et al. 2014, Necchi et al. 2019c). At least in the Hawaiian Islands, there have been many collections and a large-scale survey which did not yield gametophytes (Carlile and Sherwood 2013). In these populations, the chantransia sporophytes appear to be reproducing solely via monospores and potentially have either lost the ability to produce gametophytes or some unknown environmental trigger is missing. To date, no gametophytes of S. plantuloides have been identified and it may be that gametophytes have been collected but identified as $S$. arcuata based on morphology without DNA sequence data. With further sampling from the locations currently known for S. plantuloides and other locations in Europe, gametophytes might be identified.

Sheathia is the only genus in the Batrachospermales in which heterocortication has been identified and used as a taxonomic character (Salomaki et al. 2014). All species with heterocortication form a well-supported subclade with the exception of S. exigua which is sister to a large clade of homocorticate species (Salomaki et al. 2014, Necchi et al. 2019c, this study). Salomaki et al. (2014) hypothesized that heterocortication was subsequently lost in the homocorticate species and our study supports this view. In addition, we have added another homocorticate species, S. californica, to the phylogeny and have shown that it to be sister to all other species in the genus. Therefore, the robust phylogeny presented in this study of Sheathia provides more evidence that homocortication was the ancestral state and then secondarily lost.

With this current study, the number of species recognized in Sheathia is raised to 17 , seven heterocorticate and 10 homocorticate. This species diversity elevates Sheathia to one of the larger genera in the Batrachospermales surpassed only by Kumanoa and Nothocladus (Necchi and Vis 2012, Entwisle et al. 2016). In Kumanoa, there is a pattern of the genus being widespread but individual species being much more restricted in their distribution, typically only an island chain or small region of a single continent (Necchi and Vis 2012). Likewise, the genus Sheathia is widespread geographically with species recorded from oceanic islands and five continents with the noteworthy exception of South America. For twelve species of the genus, their distribution is restricted to a single continent or smaller geographic area, but five spe- 
cies have wider distributions over large geographic distances.

\section{ACKNOWLEDGEMENTS}

We gratefully acknowledge the individuals listed in Supplementary Table S1 for collection of specimens. We thank Lexie Redmond and Emily Keil for assistance with some of the laboratory work. Nadia Abdelahad kindly allowed us to reuse a Sheathia specimen from Italy with previous $r b c \mathrm{~L}$ data for COI-5P sequencing. Tim Entwisle and NevilleWalsh provide invaluable advice regarding the use of Latin for naming the species. Funding for portions of the research was provided by NSF grants (DEB0936855, DEB1655230) and the Polish Ministry of Sciences and Higher Education grant (N N304 285937). The specimens from California were collected as part of the Surface Water Ambient Monitoring Program (SWAMP) of the California State Water Resources Control Board, which provided funding for this research. Any opinions, findings, and conclusions or recommendations expressed in this material are those of the authors and do not necessarily reflect the views of NSF.

\section{SUPPLEMENTARY MATERIALS}

Supplementary Table S1. Species designation from this study and prior to this study, collection information, and GenBank accession numbers for specimens of Sheathia used in this study (https://www.e-algae.org/).

Supplementary Table S2. Outgroup sequences used for phylogenetic analyses (https://www.e-algae.org/).

Supplementary Fig. S1. Results from Automatic Barcode Gap Discovery (ABGD) using all $r b c \mathrm{~L}$ sequences for Sheathia species with homocortication in Supplementary Table S1 (https://www.e-algae.org/).

Supplementary Fig. S2. Results from Automatic Barcode Gap Discovery (ABGD) using all 5' region of the cytochrome $c$ oxidase subunit I (COI-5P) sequences for Sheathia species with homocortication in Supplementary Table S1 (https://www.e-algae.org/).

\section{REFERENCES}

Abdelahad, N., Bolpagni, R., Lasinio, G. J., Vis, M. L., Amadio, C., Laini, A. \& Keil, E. J. 2015. Distribution, morphology and ecological niche of Batrachospermum and She- athia species (Batrachospermales, Rhodophyta) in the fontanili of the Po plain (northern Italy). Eur. J. Phycol. 50:318-329.

Carlile, A. L. \& Sherwood, A. R. 2013. Phylogenetic affinities and distribution of the Hawaiian freshwater red algae (Rhodophyta). Phycologia 52:309-319.

Chapuis, I. S. 2016. Batrachospermales (Rhodophyta) from the Iberian Peninsula and the Balearic Islands: diversity and phylogeny. Ph.D. dissertation, Universidad de Granada, Granada, 175 pp.

Chapuis, I. S., Necchi, O. Jr., Zuccarello, G. C., Xie, S. -L., Aboal, M., Sánchez Castillo, P. M. \& Vis, M. L. 2017. A new genus, Volatus and four new species of Batrachospermum sensu stricto (Batrachospermales, Rhodophyta). Phycologia 56:454-468.

Chiasson, W. B., Johanson, K. G., Sherwood, A. R. \& Vis, M. L. 2007. Phylogenetic affinities of the form taxon Chantransia pygmaea (Rhodophyta) specimens from the Hawaiian Islands. Phycologia 46:257-262.

Chou, J. -Y. \&Wang, W. -L. 2006. Batrachospermum arcuatum Kylin (Batrachospermales, Rhodophyta), a freshwater red alga newly recorded in Taiwan. Taiwania 51:58-63.

Eloranta, P., Kwandrans, J. \& Kusel-Fetzmann, E. 2011. Rhodophyceae and Phaeophyceae; Süßwasserflora von Mitteleuropa. Band 7. Spectrum Akademischer Verlag, Heidelberg, $155 \mathrm{p}$.

Entwisle, T. J., Johnston, E. T., Lam, D. L., Stewart, S. A. \& Vis, M. L. 2016. Nocturama gen. nov., Nothocladus s. lat. and other taxonomic novelties resulting from the further resolution of paraphyly in Australasian members of $\mathrm{Ba}$ trachospermum (Batrachospermales, Rhodophyta). J. Phycol. 52:384-396.

Han, J. -F., Nan, F. -R., Feng, J., Lv, J. -P., Liu, Q., Kociolek, J. P. \& Xie, S. -L. 2018. Sheathia jinchengensis (Batrachospermales, Rhodophyta), a new freshwater red algal species described from North China. Phytotaxa 367:63-70.

Han, J. -F., Nan, F. -R., Feng, J., Lv, J. -P., Liu, Q., Lui, X. -D. \& Xie, S. -L. 2019. Sheathia matouensis (Batrachospermales, Rhodophyta), a new freshwater red algal species from North China. Phytotaxa 415:255-263.

Hua, D. \& Shi, Z. -X. 1996. A new species of Batrachospermum from Jiangsu, China. Acta Phytotaxon. Sin. 34:324326.

Huelsenbeck, J. P. \& Ronquist, F. 2001. MRBAYES: Bayesian inference of phylogenetic trees. Bioinformatics 17:754755.

Ji, L., Xie, S. -L., Feng, J., Chien, L. \&Wang, J. 2014. Molecular systematics of four endemic Batrachospermaceae (Rhodophyta) species in China with multilocus data. J. Syst. Evol. 52:92-100. 
Johnston, E. T., Lim, P. -E., Buhari, N., Keil, E. J., Djawad, M. I. \&Vis, M. L. 2014. Diversity of freshwater red algae (Rhodophyta) in Malaysia and Indonesia from morphological and molecular data. Phycologia 53:329-341.

Kumano, S. 2002. Freshwater red algae of the world. Biopress Ltd., Bristol, 375 pp.

Kylin, H. 1912. Studien über die schwedischen Arten der Gattungen Batrachospermum Roth und Sirodotia nov. gen. Nova Acta Reg. Soc. Sci. Upsal. Ser. 4 3:1-40.

Li, Q., Ji, L. \& Xie, S. -L. 2010. Phylogenetic analysis of Batrachospermales (Florideophyceae, Rhodophyta) based on chloroplast $r b c \mathrm{~L}$ sequences. Acta Hydrobiol. Sin. 34:2028.

Necchi, O., Agostinho, D. C. \& Vis, M. L. 2018. Revision of Batrachospermum section Virescentia (Batrachospermales, Rhodophyta) with the establishment of the new genus Virescentia stat. nov. Crytogam. Algol. 39:313-338.

Necchi, O., Garcia Filho, A. \& Paiano, M. O. 2019a. Revision of Batrachospermum sections Acarposporophytum and Aristata (Batrachospermales, Rhodophyta) with the establishment of the new genera Acarposporophycos and Visia. Phytotaxa 395:51-65.

Necchi, O., Garcia Fo., A. S., Paiano, M. O. \& Vis, M. L. $2019 b$. Revision of Batrachospermum section Macrospora (Batrachospermales, Rhodophyta) with the establishment of the new genus Montagnia. Phycologia 58:582-591.

Necchi, O. \& Vis, M. L. 2012. Monograph of the genus $\mathrm{Ku}$ manoa (Rhodophyta, Batrachospermales). Bibl. Phycol. 116:1-79.

Necchi, O., West, J. A., Ganesan, E. K., Yasmin, F., Rai, S. K. \& Rossignolo, N. L. 2019c. Diversity of the genus Sheathia (Batrachospermales, Rhodophyta) in northeast India and east Nepal. Algae 34:277-288.

Puillandre, N., Lambert, A., Brouillet, S. \& Achaz, G. 2012. ABGD, Automatic Barcode Gap Discovery for primary species delimitation. Mol. Ecol. 21:1864-1877.

Salomaki, E. D., Kwandrans, J., Eloranta, P. \& Vis, M. L. 2014. Molecular and morphological evidence for Sheathia gen. nov. (Batrachospermales, Rhodophyta) and three new species. J. Phycol. 50:526-542.

Saunders, G. W. 2005. Applying DNA barcoding to red macroalgae: a preliminary appraisal holds promise for fu- ture applications. Philos. Trans. R. Soc. Lond. B Biol. Sci. 360:1879-1888.

Stamatakis, A. 2014. RAxML version 8: a tool for phylogenetic analysis and post-analysis of large phylogenies. Bioinformatics 30:1312-1313.

Szinte, A. L., Taylor, J. C., Abosede, A. T. \& Vis, M. L. 2020. Current status of the freshwater red algal diversity (Rhodophyta) of the African continent including description of new taxa (Batrachospermales). Phycologia 59:187199.

Thiers, B. 2020 (continuously updated). Index herbariorum: a global directory of public herbaria and associated staff. New York Botanical Garden's Virtual Herbarium. Available from: http://sweetgum.nybg.org/ih/. Accessed Jul 10, 2020.

Vis, M. L., Feng, J., Chiasson, W. B., Xie, S. -L., Stancheva, R., Entwisle, T. J., Chou, J. -Y. \& Wang, W. -L. 2010. Investigation of the molecular and morphological variability in Batrachospermum arcuatum (Batrachospermales, Rhodophyta) from geographically distant locations. Phycologia 49:545-553.

Vis, M. L., Lee, J., Eloranta, P., Chapuis, I. S., Lam, D. W. \& Necchi, O. Jr. 2020. Paludicola gen. nov. and revision of the species formerly in Batrachospermum section Turfosa (Batrachospermales, Rhodophyta). J. Phycol. 56:844-861.

Vis, M. L., Saunders, G. W., Sheath, R. G., Dunse, K. \& Entwisle, T. J. 1998. Phylogeny of the Batrachospermales (Rhodophyta) inferred from $r b c \mathrm{~L}$ and $18 \mathrm{~S}$ ribosomal DNA gene sequences. J. Phycol. 34:341-350.

Vis, M. L., Sheath, R. G. \& Cole, K. M. 1996. Distribution and systematics of Batrachospermum (Batrachospermales, Rhodophyta) in North America. 8b. Section Batrachospermum: previously described species excluding $B a$ trachospermum gelatinosum. Eur. J. Phycol. 31:189-199.

Vis, M. L., Sheath, R. G. \& Entwisle, T. J. 1995. Morphometric analysis of Batrachospermum section Batrachospermum (Batrachospermales, Rhodophyta) type specimens. Eur. J. Phycol. 30:35-55.

Xie, S. -L. \& Feng, J. 2007. Batrachospermum hongdongense (sect. Batrachospermum, Batrachospermaceae), a new species from Shanxi, China. Bot. Stud. 48:459-464. 